\title{
Mediolateral oblique projection in mammography: Use of different angulation for patients with different thorax anatomies
}

\author{
Anja Bedene1, Erna Alukić ${ }^{2}$ Janez Žibert², Nejc Mekiš \\ 'Institute of Oncology, National Breast Cancer Screening department - DORA, Zaloška 2, 1000 Ljubljana, Slovenia, \\ 2University of Ljubljana, Faculty of health sciences, Medical imaging and radiotherapy department, Zdravstvena pot 5, \\ 1000 Ljubljana, Slovenia
}

\begin{abstract}
Introduction: The literature describes that MLO projection is not done only with angulation of $45^{\circ}$ but there is a wider span of angles that can be used. Therefore, we have investigated if the use of alternative angulation in mammographic imaging in relation to specific patient anatomies shows more breast tissue.

Methods: MLO mammograms form 491 patients that had a mammography imaging performed at alternative and basic angulation were included in the study. Angulation of $55^{\circ}$ was performed when patient had small breasts and convex sternum. The angle of $35^{\circ}$ was used for patients with large breasts and concave sternum as well as for patients with shorter thoraxes. Measurements assessed the width of the pectoral muscle, the retromammary part, and the inframammary part of the breast for both projections (alternative and basic).
\end{abstract}

Results: When comparing the angulations of $45^{\circ}$ and $55^{\circ}$, all three measured widths were in favour of $55^{\circ}$ : the pectoral muscle was on average wider by $4 \%$, the basal part by $1.3 \%$, and the inframammary part by $29 \%$. When comparing angulations of $35^{\circ}$ and $45^{\circ}$, at the angulation of $35^{\circ}$, the basal part was wider by $3.3 \%$ and inframammary part by $32.4 \%$. There were no differences in the width of the pectoral muscle between mentioned angulations.

Conclusion: Based on our results, we recommend the use of a $55^{\circ}$ angle as more appropriate for patients with longer thoraxes and small breasts and the use of a $35^{\circ}$ angle for those with shorter thoraxes and large breasts.

Key words: Breast; digital mammography; female; mammography; patient positioning

\section{INTRODUCTION}

Breast cancer is one of the most common malignant diseases in the Western world among middle-aged

\footnotetext{
*Corresponding author: Nejc Mekiš, University of Ljubljana, Faculty of health sciences, Medical imaging and radiotherapy department, Zdravstvena pot 5, 1000 Ljubljana, Slovenia. Phone: +386-1-300-11-51. E-mail: nejc.mekis@zf.uni-lj.si
}

Submitted: 12 January 2019/Accepted: 30 March 2019 women. Due to its high incidence, it is a significant health and economic problem. According to the number of patients diagnosed annually, Slovenia is in the middle third of the global ranking. Despite the rapid development of medicine, half of the cases of breast cancer are discovered too late, when the disease is no longer in a limited stage. Breast cancers can be detected early by a simple method, screening mammography, at a stage when tumors are not yet palpable and do not exceed ten millimeters in size (1).
DOI: https://doi.org/10.17532/jhsci.2019.854 
Screening programs for the early detection of breast cancer are organized throughout the world (2). Breast screening has the potential to effectively reduce breast cancer mortality (3-6) by at least $40 \%$ (7). In Slovenia, a screening program called DORA spread throughout the country from 2008 to 2017. Women aged 50-69 years are invited to receive preventive mammography every 2 years by written invitation (2). In the screening program, potential patients are sought, so healthy women are invited (8).

Mammography is, therefore, a unique and the most effective method of early detection of breast cancer and, consequently, a method that reduces the mortality of breast cancer $(9,10)$. In screening mammography, the radiographer is responsible for performing a mammogram with a high diagnostic value, while avoiding the pain caused by the compression of breasts $(7,11)$. The purpose of mammography is to achieve an optimal image, which means the maximum visualization of breast tissue with minimal discomfort for the patient.

Basic mammography has two projections: craniocaudal (CC) and mediolateral oblique (MLO). To achieve an optimal image, the breast must be correctly positioned and compressed. The image has to be highly contrasted with high sharpness, has as little noise as possible and without any artifacts. Besides that, the image has to be made with the lowest dose of radiation possible $(11,12)$. With advances in hardware and software, factors such as sharpness, noise, and contrast have become automatically optimized. The radiographer remains responsible for two factors: Positioning and compression. With adequate positioning, all possible artifacts can be removed while discomfort for the patient can be simultaneously reduced. In mammographic imaging, it is essential to position correctly the whole patient and not just the breasts (13).

MLO projection is considered to be a more superior projection, in comparison to CC, because it shows a larger part of the breast tissue on the image $(14,15)$. In the MLO projection, the outer upper quadrant is also visible, that is, important because it has been proven that the incidence of breast cancer is higher in that region (16-18). There are several different criteria used to assess the quality of the mammographic image. In each system, the quality of the image and visibility of the pectoral muscles are key to demonstrating that the entire breast is shown on the image $(9,10)$. Each breast has a different position on the thorax; all are positioned on the front wall of the chest between the $2^{\text {nd }}$ and the $6^{\text {th }}$ rib (19-21). Because of the individual chest structure, each breast is positioned differently $(9,13)$. To achieve an optimal mammogram, we need to be able to recognize the specificities (body anatomy) of each patient and adjust the angulation (in MLO projection) of the mammographic device (11).

The shape of the pectoral muscle on the MLO projection can be convex or straight (22), and the shape of the pectoral muscle affects the shape of the sternum and spinal cord (11). The recommendations and reviewed studies indicate that the primary angle of the MLO projection is $45^{\circ}$, which can be individually changed by $\pm 10^{\circ}$. The use of incorrect angulation of the $\mathrm{C}$-arm can result in an insufficient presentation of the pectoral muscle and breast tissue (13).

Based on several types of classifications used to assess the quality of mammographic images (6,23-26), and recommendations $(13,14,27)$ for performing MLO projection, we wanted to evaluate the impact of alternative angulation and its impact on breast tissue representation with patients of different constitutional type.

\section{METHODS}

In a retrospective study with secondary analysis, we have evaluated the mammographic images of the patients that underwent the MLO imaging at the alternative angulation of $55^{\circ}$ or $35^{\circ}$ depending on their body structure. The patients that have been included in the study had additional imaging done at the angulation of $45^{\circ}$ for tomosynthesis due to uncertain screening report. The retrospective methodology was chosen due to the ethical justification of the study, because performing two images just for a research reason in mammography are not justified. All of the images were performed on a digital mammography unit.

In our study, an angulation of $55^{\circ}$ was performed for patients, who had small breasts, convex sternum and problems with spine and pain in shoulders and angulation of $35^{\circ}$ for patients with short-term chest 
and large breasts. The angulation was performed and decided by the radiographers performing the screening mammographic imaging. All the radiographers in the Slovenian screening program are evaluated by a specialized radiographer, and the scoring of each mammography image that is evaluated must exceed an average score of $75 \%$. Therefore, all the images performed by screening radiographers have the same quality so that the positioning knowledge of the radiographers does not affect the results of the study. The patient size sample was calculated using the Gpower 3.1 tool. Based on the results, the sample size of patients with angulation of $55^{\circ}$ was 248 , and the sample size of patients with angulation of $35^{\circ}$ was 243 . These calculations were performed on preliminary results before the research. The images that were inspected in the study were performed between March 2016 and December 2016. This study was approved by the National Medical Ethics Committee (0120-98/2017/12) and Hospital Ethics committee (ERID-EK/55). All of the personal patients' information were anonymized before the study.

\section{Measurements}

In mammographic imaging evaluation or measurements, the tissue of the breast that has to be represented on the image must be considered for optimal diagnostic purposes. Based on the classifications, the MLO projection must represent the whole breast, pectoral muscle, retromammary part of the breast, and whole posterior nipple line (NL). The measurements were performed on three different reference points (Figure 1):

- The width of the pectoral muscle (the whole visible part of the muscle was measured at the top of the MLO image),

- Retromammary part of the breast (NL from the middle of the nipple horizontally to the end of the breast or to the beginning of the pectoral muscle),

- Inframammary part of the breast (from the lower edge to the end of breast tissue).

The images included in the study were accepted by two reporting radiologists in a mammography screening program as acceptable for diagnostic purposes. Because we have set up a strict measurement protocol, we have decided that it is acceptable that

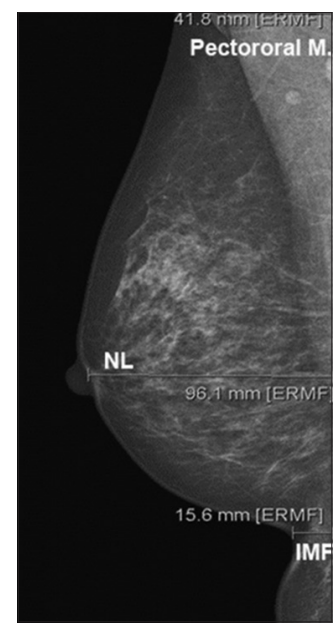

FIGURE 1. Sample of measurements on mentioned reference points.

the images are evaluated by one trained screening radiographer. All the measurements were performed on a Barco monitor model GS520, quality control of the monitor was performed before the study and viewing conditions were set at 10 lux.

\section{Statistical analysis}

Data were analyzed using IBM SPSS statistic version 25. Normal distribution was tested using the Shapiro-Wilk test. When the data were normally distributed, a related samples $t$-test was performed; and the data were non-normally distributed, a related samples Wilcoxon signed-rank test was used. The significance of $p<0.05$ was used for all the tests.

\section{RESULTS}

The presented results are separated for comparison of $55^{\circ}$ angulation against $45^{\circ}$, and $35^{\circ}$ angulation against $45^{\circ}$, depending on specific patient anatomy described in the methodology.

\section{Comparison of $45^{\circ}$ and $55^{\circ}$ angulation in MLO projection}

When comparing the presented tissue of the breasts between $45^{\circ}$ and $55^{\circ}$, all the results were in favor of $55^{\circ}$. The pectoral muscle was on average wider for $4 \%$, basal part of the breast for $1.3 \%$, and inframammary part for $29 \%$. All the results are presented in Table 1. 
TABLE 1. Basic statistical characteristics of the measurements for angulation of $55^{\circ}$ and $45^{\circ}$

\begin{tabular}{|c|c|c|c|c|c|c|}
\hline & Average $(\mathrm{mm})$ & $\mathrm{SD}(\mathrm{mm})$ & Median (mm) & Minimum $(\mathrm{mm})$ & Maximum (mm) & $p$ value \\
\hline${ }^{\dagger}$ Pectoral muscle $55^{\circ}$ & 49.6 & 11.9 & 49.9 & 22.0 & 89.0 & $<0.001$ \\
\hline${ }^{\dagger}$ Pectoral muscle $45^{\circ}$ & 47.8 & 10.3 & 47.8 & 21.1 & 78.1 & \\
\hline${ }^{\dagger}$ Basal part $55^{\circ}$ & 94.3 & 31.8 & 89.5 & 38.4 & 169.8 & 0.012 \\
\hline tBasal part $45^{\circ}$ & 93.1 & 30.4 & 89.1 & 38.9 & 167.4 & \\
\hline${ }^{\dagger}$ Inframammary part $55^{\circ}$ & 4.3 & 4.7 & 3.6 & 0 & 29.2 & $<0.001$ \\
\hline${ }^{\dagger}$ Inframammary part $45^{\circ}$ & 3.3 & 5.1 & 0 & 0 & 23.5 & \\
\hline
\end{tabular}

${ }^{\dagger}$ Non-normally distributed data

TABLE 2. Basic statistical characteristics of the measurements for angulation of $35^{\circ}$ and $45^{\circ}$

\begin{tabular}{lcccccc}
\hline & Average $(\mathrm{mm})$ & SD $(\mathrm{mm})$ & Median $(\mathrm{mm})$ & Minimum $(\mathrm{mm})$ & $\begin{array}{c}\text { Maximum } \\
(\mathrm{mm})\end{array}$ & $p$ value \\
\hline${ }^{\dagger}$ Pectoral muscle $35^{\circ}$ & 47.8 & 13.3 & 48.2 & 16.6 & 85.5 & 0.493 \\
${ }^{\dagger}$ Pectoral muscle $45^{\circ}$ & 48.3 & 13.2 & 49.2 & 7.3 & 80.4 & \\
Basal part $35^{\circ}$ & 142.7 & 29.8 & 141.3 & 60.5 & 228.8 & $<0.001$ \\
Basal part 45 & 138.1 & 29.7 & 136.5 & 57.3 & 220.0 & \\
${ }^{\dagger}$ Inframammary part $35^{\circ}$ & 7.5 & 6.5 & 7.6 & 0 & 30.9 & $<0.001$ \\
${ }^{\dagger}$ Inframammary part $45^{\circ}$ & 5.1 & 5.9 & 3.2 & 0 & 26.1 & \\
\hline
\end{tabular}

${ }^{\dagger}$ Non-normally distributed data

\section{Comparison of $35^{\circ}$ and $55^{\circ}$ angulation in MLO projection}

When comparing the presented tissue of the breasts between $35^{\circ}$ and $55^{\circ}$, the results for basal part of the breast and the inframammary part of the breast were in favor of $35^{\circ}$. No statistically significant difference between the width of the pectoral muscle in the examined projections was found. The basal part of the breast was wider by $3.3 \%$ and inframammary part by $32.4 \%$. All the results are presented in Table 2 .

\section{DISCUSSION}

The study was aimed to investigate whether the use of alternative $\left(35^{\circ}\right.$ or $\left.55^{\circ}\right)$ angulation in MLO projection represents more breast tissue instead of standard projection with a $45^{\circ}$ angle, for patients with specific anatomy.

Patients that are referred to mammography are of different ages and sizes and have different body anatomy; among them, they could be women with small or large breasts, with a concave or convex sternum. In addition to all relevant positioning skills and anatomical knowledge, the radiographer needs a thorough knowledge of the various projections and adjustments to meet the needs of individual patients $(9-11,13)$.
We did not find any study in the reviewed literature that compared the alternative angulations in MLO projection. However, many studies indicate the theoretical starting points that comply with our research $(14,22,27,28)$.

These angles are in the range of $40-60^{\circ}(14,22)$, $30-60^{\circ}$ (27), and $30-70^{\circ}$ (28). Each study states the use of different angle that differs in relation to the anatomy of the breasts, chest, sternum, and height of the patients. Miller (22) recommends the use of a steeper angle in patients with longer chest and small breasts, and the use of a lesser angle for patients with shorter chest and large breasts. Eklund et al. (14) in the other study suggested angulation of $60^{\circ}$ for higher patients with a longer thorax and a convex sternum, and $40^{\circ}$ for smaller patients, with a shorter thorax and a concave sternum. These articles are consistent with our theory and practice in the DORA program.

With the use of $55^{\circ}, 1.8 \mathrm{~mm}$ (4\%) more width of the pectoral muscle is shown; consequently, lymph nodes in the pectoral muscle are also shown better by $2.1 \mathrm{~mm}(4.5 \%)$. More of the basal/retromammary part of the breast is shown, by $1.2 \mathrm{~mm}(1.3 \%)$. The basal/retromammary part is vital for positioning. Each millimeter of basal tissue could provide 
the possibility of detecting changes in the breast. The inframammary part of the breast is also shown more with the use of angulation $55^{\circ}$ by $1 \mathrm{~mm}$, which represents $29 \%$. With our measurements, we could prove that using an angle of $55^{\circ}$ shows more breast tissue than the standard angle of $45^{\circ}$.

A comparison of the measured values on the mammograms between the angles of $35^{\circ}$ and $45^{\circ}$ confirms that breast tissue is shown better in two measurements with the use of $35^{\circ}$. Using an angle of $35^{\circ}$ shows an average of $4.6 \mathrm{~mm}(3.3 \%)$ more basal/ retromammary part of the breast, and the inframammary area by $2.4 \mathrm{~mm}(32.4 \%)$.

Hertl (29) states that for reading of the mammogram the important areas are: Milky way (wide area in front of the pectoral muscle), no man's land (the space between the chest wall and the end of the glandular tissue), medial, and the retromammary part of the breast, where tumors spread more easily because of the plexus of lymphatic vessels in this area. Most breast cancers begin in the glands that make breast milk and the ducts that carry milk to the nipple. Therefore, the focus is according to the literature higher on a sufficient shown of retromammary space than on the other parts of the breast (29-31). All of these parts are better shown when a $55^{\circ}$ or $35^{\circ}$ angle is used for a woman with specific anatomic features.

\section{CONCLUSION}

We have found that the use of alternative angulation in MLO projection based on patient anatomy can increase the representation of the breast tissue in mammographic imaging. The angle of $55^{\circ}$ was used for patients with small breasts, convex sternum, and problems with spine and shoulders. When comparing $45^{\circ}$ and $55^{\circ}$ angle, all three measurements (the width of the pectoral muscle, the retromammary space, and inframammary part of the breast) were statistically significant in favor of $55^{\circ}$. The angle of $35^{\circ}$ was used for patients with large breasts, poorly palpable inframammary regions, concave sternum, and breasts that are expanded together as well as for patients with shorter thoraxes. An angulation of $35^{\circ}$ showed more retromammary and inframammary parts of the breast compared to the standard angle of $45^{\circ}$, while there was no statistically significant difference between the representations of the width of the pectoral muscle. In the future personalized alternative angulation in MLO projection can be examined based on specific patient anatomy.

\section{REFERENCES}

1. Kadivec M, Krajc M. Presejalni program DORA za zdravje žensk. In Pacientke z Rakom Dojk-trendi in Novosti. Ljubljana: Sekcija Medicinskih Sester in Zdravstvenih Tehnikov v Onkologiji pri Zbornici Zdravstvene in Babiške Nege Zveza Strokovnih Društev Medicinskih Sester, Babic in Zdravstvenih Tehnikov Slovenije; 2013. p. 14-22.

2. Delić A. Kritični Pogled in Ocena Koristi Državnega Programa za Obvladovanje Raka Skozi Prizmo Treh Državnih Presejalnih Programov: Zora, Dora in Svit, v Povezavi z Okoljskimi Dejavniki. Nova Gorica; 2015.

3. Helvie MA, Chang JT, Hendrick RE, Banerjee M. Reduction in late-stage breast cancer incidence in the mammography era: Implications for overdiagnosis of invasive cancer. Cancer 2014;120(17):2649-56. https://doi. org/10.1002/cncr.28784.

4. Tabar L, Vitak B, Chen HT, Yen MF, Cohen A, Tot T, et al. Swedish twocounty trial: Impact of mammographic screening on breast cancer mortality during 3 decades. Radiology 2011;260(3):658-63.

https://doi.org/10.1148/radiol.11110469.

5. Kalager M, Zelen M, Langmark F, Adami HO. Effect of Screening mammography on breast-cancer mortality in Norway. $\mathrm{N}$ Engl $\mathrm{J}$ Med 2010;363(13):1203-10. https://doi.org/10.1056/nejmoa1000727.

6. Balleyguier C, Cousin M, Dunant A, Attard M, Delaloge S, Arfi-Rouche J. Patient-assisted compression helps for image quality reduction dose and improves patient experience in mammography. Euro $\mathrm{J}$ Cancer 2018;103:137-42.

https://doi.org/10.1016/j.ejca.2018.08.009.

7. Agius EC, Naylor S. Breast compression techniques in screening mammography A Maltese evaluation project. Radiography 2018;24(4):309-14. https://doi.org/10.1016/j.radi.2018.03.007.

8. Kadivec M, Krajc M, Hertl K, Jarm K, Žakelj MP, Šval C. Državni presejalni program za raka dojke program zgodnjega odkrivanja raka dojke. In: Završnik J, editor. Bolezni Dojke. Maribor: V: Simpozij Bolezni Dojke, Zdravstveni dom dr. Slovenia: Adolfa Drolca; 2014. p. 221-8.

9. Spuur K, Poulos A. Evaluation of the pectoral muscle in mammography images: The Australian experience. Euro J Radiogr 2009;1(1):12-21. Available from: https://doi.org/10.1016/j.ejradi.2008.11.003

10. Bentley K, Poulos A, Rickard M. Mammography image quality: Analysis of evaluation criteria using pectoral muscle presentation. Radiography 2008;14(3):189-94. https://doi.org/10.1016/j.radi.2007.02.002.

11. Krajnc Z, Rener M, Rataj A, Rusjan P, Novak G, Čebulj K. Pozicioniranje in kontrola kakovosti mamograma. Radiol Oncol 2004;38 Suppl 1:35-49.

12. Rener M, Hertl K, Guna F. Klinična presoja kakovosti mamogramov. Radiol Oncol 2001;35 Suppl 1:7-18.

13. Popli MB, Teotia R, Narang M, Krishna H. Breast positioning during mammography: Mistakes to be avoided. Breast cancer: Basic and clinical research. Lib Acad 2014;8:119-24.

https://doi.org/10.4137/bcbcr.s17617.

14. Eklund GW, Cardenosa G. The art of mammographic positioning. Radiol Clin North Am 1992;30(1):21-53.

15. Eklund GW, Cardenosa G, Parsons W. Assessing adequacy of mammographic image quality. Radiology 1994;190(2):297-307.

https://doi.org/10.1148/radiology.190.2.8284372.

16. Royal Australian and New Zealand College of Radiologists. Mammography Quality Assurance Program. 2002 Available from: https://www.ranzcr.com/ fellows/clinical-radiology/quality-assurance-and-accreditation/mqap. [Last accessed on 2019 Feb 23]. 
17. National Accreditation Standards BreastScreen Australia Quality Improvement Program. Australian Government Department of Health and Aging; 2001.

18. The Royal Australian and New Zealand College of Radiologists. Guidelines for Quality Control Testing for Digital (CR and DR) Mammography. The Faculty of Clinical Radiology; 2018.

19. Tortora GJ, Derrickson BH. Principles of Anatomy and Physiology. $11^{\text {th }}$ ed. J. Wiley and Sons Inc; 2006. Available from: https://www.books.google.si/ books/about/Principles_of_Anatomy_and_Physiology_Atl.html?id=brGEbJ-KiRIC\&redir_esc=y. [Last accessed on 2019 Feb 23].

20. Martini F, Ober WC, Garrison CW, Welch K, Hutchings RT. Fundamentals of Anatomy and Physiology. $5^{\text {th }}$ ed. Upper Saddle River: Prentice Hall International; 2001.

21. Parkin G. Fundamentals of mammography. In: Lee L, Stickland V, Wilson R, Roebuck E, Saunders WB, editors. London: W.B. Saunders; 1995. 149 p. Available from: https://www.beck-shop.de/lee-wilson-stickland-fundamentals-of-mammography/product/8675064?product $=8675064$. [Last accessed on 2019 Feb 23].

22. Miller LC. Rethinking Mammography Principles: What Works and Why. Breast Imaging Symposium; 2016.

23. Nemanič P. Kontrola Kakovosti Mamografskih Slik $v$ Slovenskem Državnem Presejalnem Programu DORA. Ljubljana: Univerza v Ljubljani, Zdravstvena Fakulteta; 2016.

24. Kelly J, Millington S, Burnage J. Breast imaging. In: Medical Imaging:
Techniques, Reflection and Evaluation. 2nd ed. London: Churchill Livingstone Elselvier; 2012. p. 289-92.

25. Moreira C, Svoboda K, Poulos A, Taylor R, Page A, Rickard M. Comparison of the validity and reliability of two image classification systems for the assessment of mammogram quality. J Med Screen 2005;12(1):38-42. https://doi.org/10.1258/0969141053279149.

26. Kassenarzliche Vereinigung Bayerns. Qualitatssicherung Kurative Mammographie. KVBINFOS; 2011. p. 137-42.

27. Kovačević DO, Brnić Z, Hebrang A. Mammographic oblique views $45^{\circ}$ versus $60^{\circ}$ : Breast thickness, breast exposure and image quality. Radio Oncol 2003;37(1):5-8.

28. Peart O. Positioning challenges in mammography. Radiol Technol 2014;85(4):417-39.

29. Hertl K. Kako Odčitavamo Mamografije. Ljubljana: DORA; 2018. p. 1-11.

30. The American Cancer Society Medical and Editorial Content Team. What Is Breast Cancer? 2017. Available from: https://www.cancer.org/cancer/breast-cancer/about/what-is-breast-cancer.html. [Last accessed on 2019 Feb 23].

31. Breast Cancer Now. How Breast Cancer Starts and Grows. Health and Care Information You Can Trust. 2016. Available from: https://www.breastcancernow.org/about-breast-cancer/have-you-recently-been-diagnosedwith-breast-cancer/how-breast-cancer-starts-and-grows. [Last accessed on 2019 Feb 23]. 